\title{
LISTINA ZÁKLADNÍCH PRÁV EU V JUDIKATUŘE ITALSKÝCH SOUDU゚*
}

\author{
ELIŠKA JONÁŠOVÁ
}

\begin{abstract}
The Charter of Fundamental Rights of the $\mathbf{E U}$ in the case law of Italian courts
The paper deals with the approach of Italian courts to the application of the Charter of Fundamental Rights of the EU, particularly the Italian Constitutional Court and the willingness to apply the Charter coming from the national courts. The key documents discussed in the paper are not only the Charter and the Lisbon Treaty but also the Italian Constitution, enacted after the Second World War.

The paper deals with particular articles described in the Charter and tries to identify the nature of this European instrument in Italian law and jurisdiction. The most important players in this field are the Court of Justice of the EU, the Italian Constitutional Court and national courts officially subordinated to the Constitutional Court in this matter, however practically individual legal entities in the application of the provisions mentioned in the paper. Even though the Charter gained its specific role in the protection of fundamental rights after the Lisbon Treaty, there is still no clear division of power between the courts and between the Charter itself and the national constitution. We may still declare, on the other hand, that the positive approach to apply the European legal document in this matter within the Italian jurisdiction prevails.
\end{abstract}

Keywords: Italian jurisdiction; the Charter of Fundamental Rights of the EU; Constitutional Court; protection of fundamental rights

Klíčová slova: italské soudnictví; Listina základních práv EU; Ústavní soud; ochrana základních práv

DOI: $10.14712 / 23366478.2018 .39$

\section{1. ÚVOD}

Ochrana základních lidských práv je $\mathrm{v}$ dnešní době zajištěna nejen prostřednictvím národních právních řádů, ale také právem Evropské unie. Itálie v rámci poválečné evropské vlny ústavní přeměny $\mathrm{v}$ demokracii představila $\mathrm{v}$ roce 1947 ústavu, která byla inovativní a která jasně uznávala a chránila lidská práva. V článcích 1

* Tento výstup vznikl v rámci projektu Specifického vysokoškolského výzkumu 2017-2019 s názvem „Právní vědomí: pojem, formování, účinky se zvláštním zřetelem k působení Listiny základních práv Evropské unie na právní vědomí v České republice“, č. 260 361, řešeného na Právnické fakultě Univerzity Karlovy. 
až 11 jsou vyčteny základní principy určené k ochraně lidských práv a svobod a celá první část ústavy, členěná do čtyř kapitol, garantuje základní lidská práva týkající se především osobní a domovní svobody, práva se shromažd'ovat, náboženské svobody a sociálních práv, ekonomických a politických práv. Výslovně italská ústava neupravuje např́klad právo na lidskou důstojnost, a je tak na soudních rozhodnutích, aby tento princip odvozovaly a specifikovaly, stejně jako v př́padě principu solidarity. ${ }^{1}$

Novodobým oficiálním dokumentem evropského práva, který je aplikován k ochraně lidských práv i v italském soudnictví, je Listina základních práv EU (dále jen „Listina“). Listina sice není prŕmo inkorporována do textu Lisabonské smlouvy, která má podle Soudního dvora EU ústavní povahu, přesto zůstává nepochybný její zvláštní význam v právním řádu jednotlivých členských států. Je ovšem nutné na tomto místě také připomenout, že kromě ústavní ochrany lidských práv a ochrany poskytované Listinou poskytuje právní ochranu také Úmluva o ochraně lidských práv a základních svobod, které již byla vývojem italské judikatury přiznána možnost přímé aplikovatelnosti. Poprvé ji Úmluvě přiznal italský Nejvyšší soud v roce $1967 .{ }^{2}$

\section{APLIKACE LISTINY V ITALSKÉM PRÁVNÍM Ř́DU}

Listina, zveřejněná v Nice v prosinci roku 2000, se v rozsudcích italského ústavního soudnictví začala projevovat poměrně brzy. Italský Ústavní soud je v souladu s čl. 134 Ústavy povolán k přezkumu ústavní legitimity zákonů, řešení sporů mezi státními orgány navzájem a státními orgány a kraji a také k posouzení obvinění vůči prezidentu Italské republiky. Tento Ústavní soud ve vztahu k účinkům práva EU v rozsudku ze dne 24. 6. 2010 řekl, že zůstávají stabilní, i s ohledem na reformu, legislativní moc a mezinárodní odpovědnost státu, všechny následky, které vyplývají z omezení suverenity, v souladu s čl. 11 Ústavy. V případě možných rozporů s Ústavou zůstává stabilní záruka, na rozdíl od mezinárodních smluvních norem, že výkon normativní moci delegované na Evropskou unii má svůj limit v základních principech ústavního pořádku a v ochraně nezcizitelných práv.

Hlavní protagonisté aplikace Listiny jsou kromě Soudního dvora EU národní soudy a soudy ústavní. Soudci národních soudů mohou rozhodnout o neaplikaci právního ustanovení, které je v rozporu s Listinou, a mohou dát podnět Ústavnímu soudu k přezkumu normy a jejího souladu s Ústavou. Ústavní soud lze dnes do určité míry chápat jako evropský soud, který může v tomto směru jednat dvěma směry. Bud’ podpoří obecné soudy v úmyslu neaplikovat právní normy tam, kde je zřejmý konflikt právních ustanovení, nebo směřuje obecné soudy k bedlivému zkoumání těchto ustanovení a jejich správné interpretace, i s ohledem na rozsudky Soudního dvora EU. S tím souvisí také obecnější otázka, zda se mají obecné soudy v tomto směru obracet na Ústavní soud nebo

1 MEZZETTI, L.: Human Rights, Between Supreme Court, Constitutional Court and Supranational Courts. The Italian Experience. In ARNOLD, R. (ed.): The Convergence of the Fundamental Rights Protection in Europe. New York: Springer, 2016, s. 29-71.

2 Nejvyšší soud, rozsudek č. 2762/1967. 
na Soudní dvůr EU, nebot' se zde do určité míry projevuje souběh jurisdikcí. ${ }^{3} \mathrm{~V}$ tomto prŕspěvku jsou naznačeny některé rozsudky tak, aby mohl být nastíněn směr argumentace Ústavního soudu Listinou a aplikace Listiny italskými soudy nižších stupňủ. Niže jsou proto uvedeny některé úvahy soudů o právní povaze Listiny a jejím vztahu k italskému ústavnímu právu.

V jednom z prvních rozsudků z roku $2002,{ }^{4}$ z hlediska zmínky Listiny, ústavní soudce zohlednil existenci nového nástroje $\mathrm{k}$ ochraně základních práv, konkrétně při posuzování otázky pořizování obrazových záznamů v soukromých prostorech za účelem následného vyšetřování. Žádná ze stran argumentaci Listinou v daném př́ípadě nepoužila, a byla to tak iniciativa italského Ústavního soudu, který na ni ve své argumentaci odkázal. Obdobný př́ípad nastal ještě téhož roku, ${ }^{5}$ což vedlo k použivání argumentu Listinou zúčastněnými stranami. Výslovný odkaz na Listinu použil Ústavní soud až do současnosti ve více než sto př́ípadech, ${ }^{6}$ přičemž většinou se jednalo o incidenční řízení, tedy řízení, kdy soudce řešící konkrétní právní případ předkládá Ústavnímu soudu otázku ústavnosti zákonné normy. $V$ těchto případech je zřejmý silnější př́íklon Ústavního soudu $\mathrm{k}$ ochraně základních práv, např́klad na rozdíl od kompetenčních sporů mezi orgány či na rozdíl od klasického řizení před Ústavním soudem.

Nejčastěji odkazuje italský Ústavní soud na články 47 a 49 Listiny, které upravují právo na účinnou právní ochranu a spravedlivý proces a na zásadu zákonnosti a přiměřenosti trestných činů a trestů. Mezi další často odkazované patř́ ustanovení proti diskriminaci (čl. 21), práva dítěte (čl. 24), právo na respektování soukromého a rodinného života (čl. 7) a právo na nedotknutelnost lidské osobnosti (čl. 3). Oproti tomu nejméně je odkazováno mj. na právo na svobodu a bezpečnost (čl. 6), právo na vlastnictví (čl. 17), kulturní, náboženskou a jazykovou rozmanitost (čl. 22) či ochranu životního prostředí (čl. 37). A zatím vủbec Ústavní soud neodkázal na články týkající se práva na život (čl. 2), zákazu mučení a nelidského či ponižujícího zacházení anebo trestu (čl. 4), zákazu otroctví a nucené práce (čl. 5) či např. ochrany spotřebitele (čl. 38). Skutečnost, že tyto články nejsou využívány, spíše koresponduje s dostatečnou úrovní evropské ochrany v podobě odpovídajících právních norem italského právního rádu. Doplňkově lze také uvést, že v sedmi př́ípadech byla připomenuta Listina jako obecný lidskoprávní dokument a ve třech př́padech se Ústavní soud odvolal na její preambuli. ${ }^{7}$

První odkazy italského Ústavního soudu na Listinu v některých případech připomenuly, že se jedná o evropský dokument bez právní účinnosti. Navzdory neúspěchu

3 BARBERA, A.: La Carta dei diritti: per un dialogo fra la Corte italiana e la Corte di Giustizia [online]. 2017 [cit. 2018-05-13]. Dostupné z https://www.cortecostituzionale.it/documenti/convegni_seminari /SIVIGLIA_BARBERA.pdf.

4 Rozsudek č. 135/ 2002, Ústavní soud.

5 Rozsudek č. 445/2002, Ústavní soud.

6 NEVOLA, R.: Corte Costituzionale. La Carta dei diritti fondamentali dell'Unione europea e l'interpretazione delle sue clausole finali nella giurisprudenza costituzionale. STU 302, 2017. Dostupné např. $\mathrm{z}$ https://www.cortecostituzionale.it/documenti/convegni_seminari/STU_302_Carta_diritti_fondamentali UE.pdf.

7 NEVOLA, R.: Corte Costituzionale. La Carta dei diritti fondamentali dell'Unione europea e l'interpretazione delle sue clausole finali nella giurisprudenza costituzionale. STU 302, 2017. Dostupné např. $\mathrm{z}$ https://www.cortecostituzionale.it/documenti/convegni_seminari/STU_302_Carta_diritti_fondamentali _UE.pdf. 
Smlouvy o Ústavě pro Evropu, která měla Listinu inkorporovat do svého textu, Ústavní soud dále pokračoval v odkazu na jednotlivá ustanovení Listiny a zdůrazňoval její nadnárodní výkladovou hodnotu. Lisabonská smlouva tento soudní postoj dále posunula, nebot' výslovně uznává práva, svobody a principy v Listině zakotvené.

V rozsudku z roku $2011^{8}$ Ústavní soud uznal souběh tří různých zdrojů sloužících k ochraně lidských práv v evropském právu, a to Listinu, Úmluvu o ochraně lidských práv a základních svobod a dále také obecné principy, které vyplývají z ústavních a tradičních hodnot. Každý z těchto zdrojů má svoji vlastní funkci při výkladu a ochraně lidských práv, přičemž $v$ př́ípadě Listiny se hovoří o jejím tzv. zesmluvnění, tedy o zlepšení ochrany základních práv v prostředí Unie.Listina ve zmínkách Ústavního soudu není vždy posuzována stejným způsobem, nebot’ někdy na ni soud odkázal jen $\mathrm{z}$ důvodu podpory svých vlastních argumentů $\mathrm{k}$ obohacení a větší přesvědčivosti odůvodnění, zatímco po Lisabonské smlouvě se stává základním dokumentem, který slouží jako měřítko tvrzených porušení práv. Je nutné ovšem také konstatovat, že v př́ípadech, kdy je skutková podstata zcela upravena italským právním řádem, není možné Listinu aplikovat, nebot'v takovém př́padě jsou dány meze úkolů a pravomocí Unie. Je ovšem zdůrazňována maximální možná víceúrovňová ochrana základních práv. ${ }^{9}$

V současné době je typický odkaz na Ústavu podpořený ustanoveními Listiny, např́klad v rozsudku z roku $2016^{10}$ Ústavní soud připomněl, že princip nezbytné proporcionality trestu ve vztahu k trestnému činu vyplývá nejen z ustanovení italské Ústavy, ale rovněž z čl. 49 odst. 3 Listiny, podle kterého výše trestu nesmí být nepřiměřená trestnému činu.

Na Listinu odkazují kromě Ústavního soudu také soudy nižších stupňů, např. Odvolací soud v Ř́mě, který neaplikoval ustanovení trestního řádu týkající se bezplatné právní pomoci a př́mo aplikoval článek 47 Listiny. ${ }^{11}$ Obdobný př́ípad nastal také u florentského odvolacího soudu, který př́mo odkázal na čl. 34 odst. 2 Listiny o sociálním zabezpečení osob oprávněně pobývajících na území Unie, a ustanovení italského právního řádu, které s uvedeným článkem bylo v rozporu, následně neaplikoval. ${ }^{12}$ Je tak zajímavé, že italské soudy nižších stupňů přistoupily k Listině jako pramenu práva aktivně již od počátku a na místo ústavních norem se rozhodly odkazovat př́mo na Listinu.

$\mathrm{V}$ tomto směru je také vhodné doplnit, že jinak se soudy staví k prŕmé aplikaci Úmluvy o ochraně lidských práv a základních svobod, která ovšem př́mým zdrojem unijního práva není. Zde je zajímavým judikátem rozsudek Ústavního soudu z roku 2007,13 který vymezil, že obecný soudce nemá pravomoc rozhodnout o neaplikování zákonného aktu, u kterého shledá jeho rozpor s Úmluvou, nebot' takový tvrzený nesou-

\footnotetext{
8 Rozsudek č. 80/2011, Ústavní soud.

9 NEVOLA, R.: Corte Costituzionale. La Carta dei diritti fondamentali dell'Unione europea e l'interpretazione delle sue clausole finali nella giurisprudenza costituzionale. STU 302, 2017. Dostupné např. z https://www.cortecostituzionale.it/documenti/convegni_seminari/STU_302_Carta_diritti_fondamentali UE.pdf.

10 Rozsudek č. 236/2016, Ústavní soud, ze dne 21. záŕí 2016.

11 Rozsudek La Corte di Appello di Roma, ze dne 11. dubna 2002.

12 BARBERA, A.: La Carta dei diritti: per un dialogo fra la Corte italiana e la Corte di Giustizia [online]. 2017 [cit. 2018-05-13]. Dostupné z https:/www.cortecostituzionale.it/documenti/convegni_seminari /SIVIGLIA BARBERA.pdf.

13 Rozsudek č. 348 a 349/2007, Ústavní soud, ze dne 24. ř́ína 2007.
} 
lad je otázkou ústavněprávní povahy, a má proto být řešen v ústavní rovině. Uvedené tvrzení je pak zajímavé dát do kontextu rozsudků Soudního dvora EU Melki a Abdeli (C-188 a C-189/10).

\section{ZÁVĚR}

Z rozsudků různých italských soudů tak vyplývá jejich ochota aplikovat Listinu, která byla prrítomná již před přijetím Lisabonské smlouvy. Po vstupu Lisabonské smlouvy v platnost je zřejmé, že tento trend pouze zesílil. Bylo potvrzeno, že v případě rozporu právní normy s ustanovením Listiny je možné neaplikovat takovou normu, a to pouze s ohledem na Listinu a bez hodnocení ústavních norem. Není tak ale zřejmým způsobem vystaven vztah unijního a ústavního práva, nebot' v tomto směru se nadále jedná o dvě autonomní a stále ještě odlišné oblasti práva, které si v některých případech konkurují. Ústavní soud zde zvažuje čl. 11 Ústavy, podle kterého mj. Itálie povoluje za stejných podmínek s ostatními státy nezbytné omezení suverenity ve prospěch právního rádu zabezpečujícího mír a spravedlnost mezi národy. Nadále platí, že italská ústava je primárním zdrojem v hierarchii italských právních předpisů. ${ }^{14}$

Je nesporné, že plnou právní relevanci Listina získala až Lisabonskou smlouvou, kdy byla postavena na stejnou úroveň jako Smlouvy. Italské akademické prostředí proto hovoří o tzv. zesmluvnění Listiny, kdy nabyla většího právního významu a kdy se stala oficiálním právním nástrojem ochrany lidských práv. Italský Ústavní soud odkázal na ustanovení Listiny v desítkách případů, především v oblasti procesních zásad, v případě některých institutů trestního práva a také v oblasti rodinných a soukromých práv. Odkazy jsou dvojí povahy, bud' se jedná o doplňkově podpůrný charakter, nebo je na ustanovení Listiny odkázáno jako na závaznou normu. Př́ímou aplikaci Listiny využívají i soudy nižších stupňů, které obecně přistupují k evropskému právu stále aktivněji. Ochrana základních práv je ale také poskytována italským ústavním právem, přičemž rozhodnutí Ústavního soudu působí erga omnes a ex tunc, zatímco odmítnutí aplikace právní normy soudcem s poukazem na Listinu ponechává předmětnou normu nadále v platnosti a může být předmětem dalších sporů. ${ }^{15}$

Listina představuje nejvyšší stupeň ochrany základních lidských práv dosažený v evropském právním prostředí a její postavení je stále více upevňováno. Je nicméně třeba mít na paměti, že aplikovat Listinu na unijní instituce či státy lze pouze v př́padě, že se jedná výhradně o výkon práva Unie. Uvedené vytyčení limitů aplikace Listiny stále není zcela jednoznačné a zůstává tak úkolem dalších dialogů mezi národními soudy, Ústavním soudem a Soudním dvorem EU. Ústavní soud zde proto nemá výhradní postavení, ovšem zůstává primárně odpovědným za odlišení postavení Ústavy, Listiny a Úmluvy.

14 NEVOLA, R.: Corte Costituzionale. La Carta dei diritti fondamentali dell'Unione europea e l'interpretazione delle sue clausole finali nella giurisprudenza costituzionale. STU 302, 2017. Dostupné např. z https://www.cortecostituzionale.it/documenti/convegni_seminari/STU_302_Carta_diritti_fondamentali UE.pdf.

15 BARBERA, A.: La Carta dei diritti: per un dialogo fra la Corte italiana e la Corte di Giustizia [online], 2017 [cit. 2018-05-13]. Dostupné z https:/www.cortecostituzionale.it/documenti/convegni_seminari /SIVIGLIA_BARBERA.pdf. 
Italský Ústavní soud ve svém rozsudku z roku $2013^{16}$ konstatoval, že všechna základní lidská práva se nacházejí ve vztahu vzájemné integrace a není možné jednoznačně určit, které z nich má absolutní přednost před ostatními. $V$ případě, že by taková situace nastala, umožnil by se neomezený růst jednoho takového práva na úkor ostatních a toto právo by převážilo v různých situacích ústavně uznávaných a chráněných. Italská ústava stejně jako jiné demokratické soudobé ústavy vyžaduje kontinuitu a vzájemné vyvažování mezi principy a základními právy.

Lze proto uzavřít, že v italském právním prostředí nejsou patrné tendence $\mathrm{k}$ suverenitě italského práva, ${ }^{17}$ naopak je Listina využívána v různých soudních stupních. Evropská unie potřebuje unijní normy, které jsou v členských státech shodným způsobem vykládány, navíc poslední slovo náleží v tomto směru Soudnímu dvoru EU v Lucemburku. Otázka, která se nabízí, spočívá v posouzení, zda dostatečně širokou ochranu základních práv v Evropě poskytuje Listina prostřednictvím evropských soudců, ústavních soudců či soudců národních soudů. ${ }^{18}$ Navíc v současném zpomalení sjednocování Evropy bude úloha suverénních právních řádů opětovně diskutována. Navzdory výše uvedenému ovšem platí, že italské soudy Listinu jako právní nástroj používají, v některých př́padech i upřednostňují před Ústavou.

Mgr. et Mgr. Eliška Jonášová

Právnická fakulta Univerzity Karlovy

novackoe@prf.cuni.cz

6 Rozsudek č. 85/2013, Ústavní soud, ze dne 9. dubna 2013.

17 Suverenita ve smyslu anglického pojmu supremacy.

18 BARBERA, A.: La Carta dei diritti: per un dialogo fra la Corte italiana e la Corte di Giustizia [online], 2017 [cit. 2018-05-13]. Dostupné z https://www.cortecostituzionale.it/documenti/convegni_seminari /SIVIGLIA_BARBERA.pdf. 